\title{
THE RISE OF FEMINISM IN THE WORKS BY HENRY JAMES: SOME NARRATOLOGICAL INSIGHTS
}

ABSTRACT. James' fiction crosses many of the artificially imposed borders and often deals explicitly with social changes and their consequences, for example, the emerging role and power of women in society. James was among the first American writers to introduce feministic issues into his works. This paper explores the theme of feminism in "The Turn of the Screw", "The Jolly Corner" and The Bostonians emphasizing that in the latter James raises the problem of possibility for women of their simultaneous self-realization in family, at work, and in social life. This is still one of the most burning issues in feministic writing thus making James relevant in the 21st century. Analysing The Bostianians and shorter works by Henry James, the paper demonstrates that the writer pays a lot of attention to the issues of female personal freedom and self-realization determined by the loyalty to the institution of marriage. James depicts the growing tendency of alienation and misunderstanding between men and women, underlined in his short works and The Bostonians.

KEYWORDS: Henry James; feminism; gender roles; gender studies; narratology; narratological analysis.

1 iren.boyarkina@uniroma1.it

This paper was submitted on July $3^{\text {th }}, 2021$ and accepted for publication at the meeting of the Editorial Board held on November $16^{\text {th }}, 2021$. 
The works by Henry James do not allow simple categorization or interpretation: they are claimed by both English and American Literature, and various researchers reveal in them characteristic features of Psychological Realism, late French Realism, and Naturalism. Indeed, James' fiction crosses many artificially imposed literary borders, and often deals explicitly with various social changes and their consequences, such as the emerging role and power of women in society at the turn from the $19^{\text {th }}$ to $20^{\text {th }}$ century. Henry James' interest in this theme is widely reflected in his art, both in short works and in the novels. This paper focuses on James' "The Turn of the Screw" (1898) and "The Jolly Corner" (1908), which explore the topic of women's position in society, especially as it parallels other important social issues, and it also studies the development of this theme in The Bostonians (1886), demonstrating that James was among the first writers to raise as a question the possibility for women to achieve simultaneous self-realization in family, at work, and in social life. This is still one of the most burning issues in feminist writing today and it allows James' fiction to continue to have powerful and pressing resonance in the 21st century.

Henry James is one of the most important representatives of Psychological Realism, alongside Fyodor Dostoevsky and Edith Wharton. Psychological realism, which focuses on the motivations and internal thoughts of characters to explain their actions, became popular in the 19th and early 20th centuries. There is often a larger theme in Psychological Realism texts, with the author expressing an opinion on a societal or political issue through the characters. Henry James often expresses his opinion on the theme of women and their role in society in his writing. This theme is closely connected to his exploration of family relationships, romantic desires, and small-scale power struggles within a family or society. The close interaction of all of these themes is the peculiarity of his creative method. The strength of James' best realistic works lies in the harmony and balance between the presentation of a passionate female identity and the detached judgment about characters and society, which is a fundamental feature of Realism. The very source of Realism in his works lies in the presentation of gender roles attributed by the major social institutions and in the description of the idealized hero or heroine in these circumstances.

Let us have a closer look at the gender roles and stereotypes existing in both American and British Victorian society to analyze these works. 
"Since Victorian society could be characterized as bourgeois and forcefully male-oriented, its doctrines were organized by-and formen.... For if eighteenth-century English fiction is arguably gynocentric, eighteenth- and early nineteenth-century English society was emphatically not" (Poovey, 1984, p. ix).

One of the most important prerequisites for the model woman in the nineteenth century was a dutiful, obedient character. The woman had to abandon all the aspirations for the professional achievements, self-realization or development of talents. No professional education and instruction, except housekeeping skills (including home budget management), could distract women from being devoted entirely to their homes. As Barbara Welter observes, "It was a fearful obligation, a solemn responsibility, the nineteenth-century American woman had-to uphold the pillars of the temple with her frail white hand" (Welter, 1966, p. 152). Instead of trying to realize her own dreams and ambitions, women had to dedicate themselves to supporting their husband's career goals, business, talents, etc. In other words, according to the gender roles of a wife, mother, daughter, strictly prescribed to them in the Victorian society, women had to abide within domestic realm and be satisfied with the things men were giving to them. A 19th century woman could not go into the world to satisfy her ambitions and aspirations, she could achieve that only through the institution of marriage that allowed her to raise up the social ladder and acquire a much-desired prestige in social hierarchy. Moreover, marriage was the only legitimate possibility that could ensure a woman the important economic and social benefits that men used to achieve through education, business, and culture. Thus, confined to the gender roles as wife, mother, and household governess, women's existence was balancing between power and neediness and confined to double standards accepted in the Victorian society, hypocrisy, etc. Already in the 19 th century quite a few women were confused and uneasy with this situation. It was utterly unjust, that such "stereotypes, in fact, rigidly confined real women to prescribed roles: a daughter, a wife, a mother, a widow, as a virgin or a whore; every woman was defined by relationship-explicitly to man, implicitly to sexuality itself" (Poovey, 1984, p. 85).

According to the stereotypes of the Victorian society, the male protagonists are presented strong, confident and virile, in command of powerful positions, entitled to order, to be obeyed, to make honest money, (a woman is usually obliged to end up immoral if she 
wishes to acquire money: naturally, it is then dishonest money), and to be in control of romantic seduction and conquest. The female characters, on the contrary, belong to the romantic heroine category, with health, vivacity and beauty, submissive to the will of Fate and men, and prone to succumbing to their own sentimentality.

Faithful to the principles of Psychological Realism, Henry James meticulously depicts gender restrictions and stereotypes of Nineteenth Century society, and places his female characters in these circumstances, carefully highlighting and analyzing their behavior and its motives.

Thus, most of the women in his fiction have far less freedom and mobility than men. Moreover, the typical woman's life is often marked by confinement that sometimes resembles imprisonment. For example, the nameless Governess in "The Turn of the Screw" was confined to the Bly household in the company of two children and the housekeeper, Mrs. Grose, without any right to go away or even to contact her employer. Such isolation and lack of control significantly resembles imprisonment.

Creating his heroes and heroines in "The Turn of the Screw," "The Jolly Corner," and The Bostonians, James, on the whole, observed the mainstream tendencies of Victorian literature. However, the signs of departure from these stereotypes towards a new representation of women's aspirations for more freedom and self-realization outside the family circles, are already clearly evident in these works.

Let us first focus on the traditional Victorian characteristics of the protagonists in these texts. In "The Turn of the Screw" the employer of the Governess, known only as Uncle, fits perfectly the abovementioned hero's literary stereotype of the $19^{\text {th }}$ century. He was extremely rich and lived in a vast and imposing house in London. This rich, nice-looking gentleman in a powerful position is entitled to employ the Governess and to command her not to disturb him, hence sentencing her to take care of his niece and nephew in his Essex house by herself. In her turn, also, the Governess can be viewed as a classical example of a Victorian heroine: she is young, modest, inexperienced (read: innocent), and obedient to her patron. She is the youngest daughter of a poor vicar, hence, can be presumed to be very religious.

Likewise, in "The Jolly Corner," the male protagonist, Spencer Brydon, is also rich. He comes back to New York from Europe after a 33-year absence to take care of inherited real estate. He recon- 
structs one of his inherited houses into apartments for rent, leaving untouched the Jolly Corner, the house of his youth. Like the patron in "The Turn of the Screw," Brydon is virile, overlaid "by the experience of a man and the freedom of a wanderer, overlaid by pleasure, by infidelity" (James, 2001, p. 560). The heroine of this story, Alice Staverton, on the other hand, is modest, patient, spiritual, intelligent, and faithful to her feelings for Brydon: an ideal example of a Victorian woman. Though they are not married, she supports him in his construction activities and praises him, as it is prescribed to all good wives to do in the Victorian epoch. Alice was: "so prettily flushing, at the time, for sympathy in his triumph, she had afterwards said to him (though to a slightly greater effect of irony) that he had clearly for too many years neglected a real gift. If he had but stayed at home he would have anticipated the inventor of the sky-scraper" (James, 2001, p. 560).

Another important feature of Victorian literature implemented in both of these texts is that both male heroes are involved in economic activities: Brydon is constructing his block of flats while the Governess' patron has in all likelihood had some business related to the colonies, (no mention is made of how he came into his wealth, but his brother is dead in India, which would indicate trade there).

It is at this point in both texts where a careful reader can see that any resemblance to classical Victorian literature has passed, and it is clear that something is changed in James' depiction of female heroines. In "The Turn of the Screw," the Governess performs her educational duties at Bly absolutely independently, without any male instructions or supervision. The young lady observes that before her life was too "small, smothered." Obviously, prior to this, she had not been entrusted with much autonomy to perform her tasks, even traditionally feminine ones, such as children's education was considered at that time. The Governess reveals: "It was the first time, in a manner, that I had known space and air and freedom" (James 1966, p. 14). The metaphor here clearly shows that the Governess is beginning to feel free from the stifling prescriptions and stereotypes of Victorian society and from typical male domination and control.

Analyzing Governess' relations both with her employer and with little Miles through the lens of 'silencing a female voice,' described by Mary Beard (2014), we discover that each tried to silence the Governess, in his own way. The employer strictly forbade her from contacting him for any reason, and Miles discredited everything 
she used to say about his behavior by providing the opposite explanation about whatever she had said.

Even if the Governess breathes the air of freedom at Bly, the ghosts of the stifling Victorian society occasionally pay their visits to this part of Essex. Ghosts in this novella are a very powerful metaphor, rich in entailments and associations. The appearance of ghosts places this novella within the gothic genre, in which feminism was already a powerful and common theme. The origins of gothic literature date back to the $18^{\text {th }}$ century, to Horace Walpole's The Castle of Otranto (1765), in which women took control over an originally male-dominated castle. Another prominent gothic novel, which also raises the theme of feminism in numerous aspects is Frankenstein, or the Modern Prometheus (1818) by Mary Shelley. According to Diane Hoeveler, "the novel itself [was] appropriated as a sort of template by feminist critics with diverse approaches" (Hoeveler, 2004, p. 46). She also observes that having adopted Foucault's theories about power functioning in the society through "discourse systems,"

"feminists and critics working in the cultural studies have been interested in Frankenstein as a particularly potent discourse system, a manifestation of conflicted ideologies, working sometimes in league with its society's repressive attitudes towards women and sometimes arguing against society's negative stereotypes about the proper roles of mothers, daughters, servants, and friends" (Hoeveler, 2004, p. 49).

There are many episodes in the novel that attract attention of feminist critics. For example, there is a key episode, which emphasizes the importance of women and fear of the female body: Frankenstein's creation of a female mate and its destruction for the fear of procreation of the monsters. Indeed, "In Frankenstein, the Creature tries to force Victor to create a female companion for him. However, Victor realizes the dangerous consequences of this step: a new race that is completely hostile to humanity could emerge from this union. Hence, Victor prefers to leave the Creature to his sufferings to protect its future" (Boyarkina, 2020, p. 149).

Thus, by the time James was writing, the gothic, with its access to ghosts and other specters, had long since established itself as a place to work out gendered issues in society.

According to long tradition, ghosts represent spirits in search of revenge for the injustice they faced. In this respect, the ghost of the former governess, Miss Jessel, in "The Turn of the Screw," repre- 
sents the victim of the rigid Victorian society, which did not tolerate any illegitimate (unsanctioned) sentimental (sexual) relations for women. Her ghost always appears with a sad and desperate face, not only to vindicate herself but also, in a feminist interpretation of the metaphor, to remind of the damage that rigid gender stereotypes in Victorian society caused to women. On the other hand, Jessel's ghost serves as a typical reminder that illegitimate relations, not sanctified by marriage, could lead to moral sufferings, illness and death. As with everything in this novel, the meaning of ghosts allows for more than one interpretation. It takes just a "turn of the screw" to change the angle and sharpness of the viewpoint, and the interpretation of the imagery becomes quite different, if not wholly opposite. Indeed, this novella is a real masterpiece of ambiguity, and this peculiarity of James' creative method keeps readers interested as it permits much deeper readings.

James' great artistic skill created this masterpiece of ambiguity, which allows meaning to change, depending on the point of view a reader chooses, like an optical illusion changes according to the angle at which it is viewed. Again, it takes just a "turn of the screw" to shift the imagery, namely if the ghost shifts from the position "visible to all" to the position "visible only to the governess," the entire meaning of the story is changed. From a sane, efficient, autonomous representative of the new emerging type of woman, taking care of children's education and protecting them from ghosts, the Governess becomes a wretched neurotic victim of the restrictive Victorian society, who hallucinates and sees ghosts. Though traditionally scholars defend either one or another version, it is more productive to consider these two interpretations not as alternative ones, but as inseparable, coherent, and complementary ones. The interpretation of the heroine's behavior as sane, devoted and courageous, aimed at protecting the children from corruption by the ghosts goes hand in hand with the interpretation of her behavior as an effort to break through the limitations of the gender restrictions of the Victorian society, since she is autonomous, efficient, and courageous.

However, as a true representative of Psychological Realism, James could not overlook the fact that these changes in the women's role in society were quite recent, and, hence, the influence of the old stereotypes and restrictions of Victorian society was still very palpable. Indeed, these restrictions suppressed many socially unrealizable women's desires and aspirations. Sigmund Freud has 
clearly explained that suppressed desires (and not only sexual ones) cause neurotic states. In Dora: An Analysis of a Case of Hysteria, a paper published just three years after the publication of The Turn of the Screw, Freud (1901) explained the etymology of neurosis relevant to the case of the Governess. This fact, again, allows a rich variety of interpretations. For example, just one turn of the screw too much in the pressure of the society on the female soul, constraining a woman to bury her desires deeply and hide her aspirations for self-realization for the sake of appearances, and a seemingly sane woman becomes a hopeless, hallucinating neurotic. Or, though women try to get rid of harmful restrictions and suppressions of the Victorian society, its iron grip is perfectly perceivable and palpable, and at any moment can cause damage to a vulnerable, sensitive female personality.

A brief narrative analysis reveals that James skilfully constructs this ambiguity by means of a careful choice of imagery and narrative techniques, which actually should be considered early examples of the already emerging modernism. These techniques include an unreliable narrator, a manuscript at the basis of the story, a double narrative frame, an open ending, and ambiguous language. Modernists hold that language is an unreliable means of communication, and "The Turn of the Screw" demonstrates this persuasively. The language of the story told by the Governess allows such ample semantic lacunas that the meaning of the entire story can be changed to its complete opposite, one after the final exclamations of little "wretched" Flora, leaving Bly and the Governess, "Take me away, take me away - oh, take me away from her!" (James, 1966, p. 73).

This ambiguity, skilfully created by James, greatly contributes to the main message of the novella. The pressure of the Victorian society on the female personality forces women to suppress their aspirations and desires for more freedom and self-realization, which has a negative influence on their psychological wellbeing. Even with some positive changes evident in the gender roles (depicted by James in "The Turn of the Screw"), recently experienced pressure was still fresh in the memory, and its protracted influence might cause a nervous breakdown at any moment of a woman's life, a possibility that James dexterously built into the novella.

Expertly crafted ambiguity is also a leading characteristic feature of "The Jolly Corner," which allows for various interpretations of this ghost story. Not only we are left to wonder whether the female 
protagonist saw the same ghost as the male protagonist did and what the meaning of this ghost apparition is, but the identity of this ghost remains ambiguous.

James' male hero in this text, Spencer Dryden, comes back to the United States to supervise the reconstruction of his "apartment-house." His psychological issues immediately come to the fore. He has a brief discussion with a man in charge: "He had found himself quite 'standing up' to this personage over a failure on the latter's part to observe some detail of one of their noted conditions, and had so lucidly argued his case" (James, 2001, p. 560). Soon he started to wonder what would have happened with his life and personality, if he hadn't left for Europe: "It was mere vain egoism [...], a morbid obsession. He found all things come back to the question of what he personally might have been, how he might have led his life and 'turned out', if he had not so, at the outset, given it up" (James, 2001, p. 564).

It is normal to wonder occasionally what could have happened if another decision had been made in life or another choice had been taken. However, for Spencer this questioning became an obsession, especially after Alice says, "If he had but stayed at home he would have discovered his genius in time really to start some new variety of awful architectural hare and run it till it burrowed in a gold mine" (James, 2001, p. 560). Spencer's reaction to Alice's words confirms the power they had over him.

"He had to remember these words, while the weeks elapsed, for the small silver ring they had sounded over the queerest and deepest of his own lately most disguised and most muffled vibrations" (James, 2001, p. 560).

These vibrations, deeply buried inside his soul, are also the feelings of guilt and fear. Fear of what other self he might have become in America: a greedy immoral aggressive man of success. On the other hand, Spencer feels guilty since he betrayed the expectations of his family, of Alice, and of that other self, thus depriving him of the possibilities to realize his talents and ambitions in America.

His obsession becomes so intense that he suspects, even feels, that his other self, his alter ego, who had never left America, secretly exists somewhere in the remote parts of "The Jolly Corner." Spencer's desire to meet his alter ego turn out to be so strong that it forces him to perform compulsive actions: every night he comes to "The Jolly Corner" in search of the presence of his alternative self. 
Spencer presumably is hunting a ghost, and this fact places the text within the genre of gothic ghost story. At the same time, Spencer's behavior is suspiciously similar to the behavior of a schizophrenic suffering from a split personality, accompanied by obsessive states and obsessive-compulsive disorder. Moreover, according to the Freudian theory, and the concept of the "return of the repressed" emerging at that time, Spencer's hunt for his alter ego can be interpreted as his desire to reach his repressed unconscious. Again, James' remarkable skill in creating an ambiguous narrative makes legitimate any of these interpretations, which have certain characteristic features in common: Spencer's sensation of being split and his burning desire to get to know his missing part (his American twin), as well as to rid himself of his guilt, fear, and regrets.

At this point, the role of Alice in healing Spencer from his acute sufferings becomes very important, and the way she does it clearly demonstrates that she does not fit easily into the description of a typical Victorian female. The first difference is that (in the afternoon of her life) she was not married, while a typical Victorian woman was supposed to be married by her age. Second, she pursued a career in New York, of a delicate frugal professor. It is mainly due to the fact that Alice has very sane and clear ideas about Spencer and comprehends his confused feelings of guilt, regret, uncertainty, and his obsession with the alter ego, that the male protagonist finally finds peace within his soul and is healed from his obsessions. Brydon readily acknowledges this to Alice: "Ah, I've come to myself now - thanks to you, dearest" (James, 2001, p. 570).

Indeed, Brydon's ideas and feelings are very confused, and it is mainly due to Alice's cool reasoning and analysis that he manages finally to sort them out and find peace within himself. Brydon speculates about the possible influence remaining in America would have on his personality: "what would it have made of me? I keep wondering." (James, 2001, p. 564). He has mixed feelings about the possible outcome: ache, regrets, rage, curiosity:

"I see what it has made of dozens of others, those I meet, and it positively aches within me, to the point of exasperation, that it would have made something of me as well. Only I can't make out what, and the worry of it, the small rage of curiosity never to be satisfied" (James, 2001, p. 564).

The conversation between Spencer and Alice about a bud and a flower is an important metaphor of the confused mental state of the 
former, which reveals his guilt and regret for the things he did or failed to do in the past. Spencer confesses to Alice:

"It is only a question of what fantastic, yet perfectly possible, development of my own nature I mayn't have missed. It comes over me that I had then a strange alter ego deep down somewhere within me, as the full-blown flower is in the small tight bud, and that I just took the course, I just transferred him to the climate, that blithered him for once and forever" (James, 2001, p. 565).

The entailment ${ }^{2}$ of the flower metaphor shows that, on one hand, Spencer allows the possibility that his personality would have fully blossomed, had he stayed in America. Hence, he has feelings of guilt and regret. However, the fear of his alter ego is also present in these speculations, as Spencer adds that this flower could have been "Monstrous above all! and ... quite hideous and offensive."

With cool logic, which immediately establishes her at the same perceived intellectual level as the males, Alice indicates the illogical way of Spencer's thinking: “You don't believe that, ... if you did, you wouldn't wonder. ... What you feel - and what I feel for you - is that you'd have had power" (James, 2001, p. 565). Alice intelligently finds the right words to reassure Spencer about his numerous doubts. Whatever decision he would have taken, to leave America or to stay, and whatever person he would become, she'd have loved him anyway. She adds: "How should I not have liked you?" (James, 2001, p. 565).

In this story, the female protagonist is clearly stronger than the male one, or at least she is his equal. Due to her intelligence, Alice manages to persuade Spencer with her rational reasoning that the scary ghost he saw has nothing to do with himself, it is not Spencer or his alter ego. Indeed, Spencer finally observes: "But this brute, with his awful face - this brute's a black stranger. He is none of me, even as I might have been" (James, 2001, p. 570). And, even if it were so, Alice adds, she would have loved him the same. The wisdom and rationality of Alice, her ability to keep a cool mind, to comprehend and accept the existing circumstances marks a departure from the

2 The notion of metaphorical entailment is closely related to the notion of conceptual domain, which Kövecses defines as follows: "A conceptual domain is our conceptual representation, or knowledge, of any coherent segment of experience...This knowledge involves both the knowledge of basic elements that constitute a domain and knowledge that is rich in detail. This detailed rich knowledge about a domain is often made use of in metaphorical entailments." (Kövecses, 2010, p. 324) 
traditional Victorian stereotype of a female. She explains to Spencer: "my mind, my imagination, has worked so over what you might, what you mightn't have been to show you, you see, how I thought of you." (James, 2001, p. 570). She adds about the ghost/ alter ego: "And he isn't - no, he isn't - you!" (James, 2001, p. 571). Unlike Dorian Gray, who managed to physically destroy the deteriorated, scary portrait of his brute, corrupted alter ego, Brydon could not destroy his awful alter ego, this ghost that scared him so much, so Alice performs this task for him, cleverly separating Brydon's ghost visions from his real self and pacifying him with his ghost experience. Indeed, as Elizabeth Troesch observes, "While Brydon is terrified and repulsed by his alter ego, it is Alice who accepts, and even 'likes' him. Alice sees and accepts both of his possible identities, assisting Brydon in re-assimilating both at the end of the tale" (Troesh, 2017, p. 189). According to the longstanding tradition, usually men are in the control of females' bodies, minds, and their mental healing. In "The Jolly Corner," James reverses these gender roles and is among the first writers to put the female protagonist in the position of healing a man's obsessive states, or neurosis.

The theme of emerging feminism and the role of women in the society is further developed in The Bostonians (1886), which James conceived as the extensive social analysis of the American society. In the novel, he intended to depict the increasing feminist activities in the U.S., as he wrote to his editor Osgood:

"I wished to write a very American tale, a tale very characteristic of our social conditions, and I asked myself what was the most salient and peculiar point in our social life. The answer was: the situation of women, the decline of the sentiment of sex, the agitation on their behalf" (Matthiessen, 1981, p. 46-47).

In The Bostonians James focuses on the eternal themes of family, love, friendship, and woman's destiny; he raises social, cultural, political, ideological and moral problems in the novel. Such polyphonic treatment of themes allows James to analyze the theme of feminism in various spheres and dimensions. Compared to his dealings with it in "The Turn of the Screw" and "The Jolly Corner," James' work on the problem of women's emancipation reaches its zenith in The Bostonians; its treatment is quite modern and remains relevant in the $21^{\text {st }}$ century. The key question of the novel - the possibility of self-realization in the family, in social activities and at work for 
women - is left by James without any definite answer, which is emphasized by the open ending of the novel.

The Bostonians' publication received a mixed reception. Some critics even considered it a caricature on suffragism. Lucia T. Ames wrote about the novel, "It seems hardly worthwhile to take a trouble to issue a protest against this caricature" (Ames, 1886, p. 82), Other critics stated that James knew nothing about the fight for women's rights (Hicks, 1933, p. 113) ${ }^{3}$ : a critique James himself acknowledged in a letter to his brother William, "the sense of knowing terribly little about the kind of life I had attempted to describe" (Lubbock, 1922, p. 115-116). However, such criticism only demonstrates that these scholars failed to perceive the rich polyphony of ideas skilfully interwoven by James in this novel. As a thoughtful observer with a deep psychological insight and attention to details, James depicted the situation in the American suffragist movement at its earliest stage, including both its weak and strong points, so that a careful reader could learn some important lessons from the novel.

Looking at the issue from a different angle, some elements of narratological analysis (Pavel 1985; Bal 1997; Rimmon-Kennan 2008) are useful to analyze the way the theme of feminism is constructed and treated in the novel. The central conflict in the novel is the fight between the Tarrants, Basil Ransom and Olive Chancellor, each of them striving to get monopoly over the life and destiny of Verena Tarrant. For feminist analysis, it is fruitful to view this conflict through the lens of silencing a female voice, a longstanding tendency in the Western literature, which dates back to the times of Odyssey, according to Mary Beard (2014). This external conflict is greatly amplified by Verena's internal conflict, as she is torn between difficult choices: a professional career that includes speaking in public and friendship with Olive, or a traditional family with Ransom. The conflicts are local and are resolved in the novel: Verena is finally silenced by Ransom and when she "makes her choice" to marry him. The existential conflict, namely, women's dissatisfac-

3 Despite some researchers' claims that James knew nothing about suffragism, the writer was using not only literary sources relevant to feminism, but its historical figures as well. For example, William James attacked his brother for the use of Sara Peabody to create the personage of Miss Birdseye. (Lubbock, 1920, pp. 115-116). Robert Long suggests a possible prototype for Dr. Mary Prance. (Long, 1964, pp. 87-88) Howard Kerr holds that Cora Hutch and spiritualism influenced the figure of Verena Tarrant. (Kerr, 1964, pp. 190-222) 
tion with their role in the society, remains unsolved due to the overpowering socio-historical conditions in the $19^{\text {th }}$ century. This conflict is represented primarily through the actions, thoughts, and choices of Olive and Verena.

In the novel, James creates a subtle, romantic and somehow tragic image of the feminist Olive Chancellor. She is very clever, reads a lot and dreams of dedicating her life to feminism, fighting for women's rights, equality, freedom and happiness. However, she is too shy to speak herself and she does not like many of the people who are active in the suffrage movement. Olive dreams of a reliable friend, a companion to share her interest in feminism, which is why she becomes very attached to Verena, perceiving that she would speak publicly on this issue. However, this friendship ultimately brings suffering to Olive, since she means much less to Verena than Verena means to her. After experiencing many years of solitude, Olive was afraid to lose her new friend; however, the loss of Verena, and its associated sufferings strengthened Olive's spirit, and she dared to speak in Music Hall when Verena decided not to do so. Thus, using adept psychologism, James depicts the evolution of Olive Chancellor from a shy theorist to an active feminist by the end of the novel.

By contrast to Olive, Verena Tarrant is very beautiful, young, charming, and has an excellent memory. Upon their meeting, Olive was immediately interested in her, gradually became her friend, and invited Verena to live in her house and to dedicate herself to the cause of suffragism. Due to Verena's excellent memory, which made her a good student, Olive overestimated Verena's dedication to the case of women. The supreme target of their studies and preparations was Verena's speech in the Music Hall, which was to be the beginning of their triumphant feminist tour around fifty cities of America. Verena is sure that she finally found herself, that feminism is the vocation of her life, and that she wants to speak in public. However, she lacks a deep critical insight into suffragism, was not as ascetic as Olive, and does not hate all males, rather she readily accepts their courtship.

The peaceful state of Verena's soul is disturbed by Basil Ransom, who constantly criticizes feminism and the whole essence of her public speeches, trying to persuade Verena to abandon this "nonsense" and to marry him. Even if his reactionary views seem exaggerated, they were rather common at that time, according to Leslie Petty (Petty, 2005, p. 398). Ransom slowly manages to make her 
doubt her destiny of feminism and her dedication to it. It happens because Verena did not stand firm in her convictions about the necessity to fight for women's rights; she did not come to her belief in women's rights by herself, she did not suffer for it, but it was partially imposed on her by Olive's insistence. Though Verena grew up in the family where her mother suffered from the behavior of her father, she did not perceive the injustice of such a situation and gender inequality, or the necessity to improve the women's conditions. Since her childhood, she has heard various reformers speaking, so she can talk the talk, but she reproduces these speeches without any critical analysis.

Verena suffers since she realizes that her doubts will hurt Olive very much. She slowly, but inevitably, falls in love with Ransom, hence she is torn between her love for Ransom and her dedication to Olive, and James, a true master of Psychological Realism, skilfully renders her sufferings in this matter. James provides many touching scenes and dialogue between Verena and Olive, discussing their common cause of feminism and their friendship. Finally, Verena makes her choice: she abandons the movement to marry Basil. However, she is too passive and submissive to make this decisive step by herself, so Basil meets her in the Music Hall right before her public speech, and, by muscular force, wrenches her away and takes her to New York, presumably to the altar. For many critics, this is one of the most sensational, and unexpected endings in American literature (Petty, 2005, p. 401). What they fail to see, however, is James' belief in the need to have personal experience with gender inequality as a required pre-cursor to achieving the personal convictions to fight for women's rights in a successful feminist struggle. With just one skilful finishing touch, James completes the picture of Verena's future life and her prospective sufferings due to the gender inequality in her marriage, as he thoughtfully comments on Verena's tears, leaving the Music Hall with Basil: "It is to be feared that with this union, so far from brilliant, into which she was about to enter, these were not the last she was destined to shed" (James, 1984, p. 433).

Olive and Verena represent two different trends in the feminist movement at its rise in America; the vectors of their development go in opposite directions. While Verena is finally silenced by her man and-resumes the values of the Victorian society, abandoning the possibility of education, as well as the rights offered to her by suffragism, such as speaking in public, Olive continues her self-edu- 
cation, suffragist activism, and wins her courage and voice: an important symbolic meaning.

While Olive is a reformer, Basil, a New York lawyer and a bankrupt planter from the South, is a reformer of reformers. His political views, including his attitude to women, are very reactionary and provincial, and look back to the past, not to the future. He is convinced that all women are second class creatures, are very boring, and even disturbing if they refuse the role prescribed to them by men: women exist to make men happy. He prefers that women do not think too much and do not try to govern the world. Basil is ambitious; he wants his views to become famous through publications but all the editors refuse his articles. Secretly he even dreams to run for presidency of the U.S. so that he could put his political views into practice, but at the moment neither his legal firm nor his writing brings him money. Since Basil has very rigid ideas about gender roles (husband must provide for his wife), he would not propose to Verena, but as soon as one publisher accepted his article, he immediately asked Verena to marry him.

In The Bostonians, James combines the traditions of late French realism and naturalism with Psychological Realism. He analyzes the development of his characters within their social milieu and circumstances to establish causal relations between their feelings, actions and thoughts. Though James acknowledges the importance of social conditions in the formation of human character, he leaves his protagonists the possibility of conscious choice, for which they respond for themselves and society. James pays great attention to the Tarrants, the most ironical, grotesque personage in the novel: Selah, a fake mesmeric healer, and his weak, suffering, and capricious wife, herself the daughter of Boston abolitionists. Selah's ridiculous desire to become famous in the press gives him the idea of using Verena's eloquence for this purpose, so he imitates the initiation of her gift by laying hands on her. Seen through the prism of males 'silencing female voices', Silah's gesture is also very symbolic. Once again, it demonstrates that men are in control of female voices and sometimes allow women to speak in public, but only if it suits male purposes (Silah's popularity in this case). The absurd and comic personage of Silah foregrounds the idea that such ridiculous and inconsistent men believe they can control female voices and their fight for equal rights.

In The Bostonians, James highlights the emerging tendency that women get less and less in a marriage; "wife" is no vocation for life. 
This idea becomes more frequent in the family novels after this time period, as James was one of the first American writers to introduce these issues into the family novel. The main problem raised in The Bostonians - the possibility for women to have a simultaneous self-realization in family, at work, and in social activities - is still one of the burning topics in modern feminist writing.

Attentive reading of The Bostonians demonstrates both weak and strong points of American feminism at the turn of the century: its disunity, inhomogeneity, lack of strong personal convictions of the necessity to fight for women's rights and critical insights into feminist issues on behalf of some activists. The novel can teach $21^{\text {st }}$ century feminist activists some important lessons: the necessity of strong unity between all social stratums involved in the struggle, the importance of personally experiencing gender inequality, and the need for personal conviction to struggle for change, as well as the necessity of education. Verena's example teaches that it is not possible to involve all stratums into the struggle for women's rights until they clearly realize the injustice of gender inequality and the necessity to fight against it.

Although "The Turn of the Screw" and "The Jolly Corner" are primarily Gothic novellas, where James on the whole followed gender stereotypes of the Victorian era, they can be also interpreted as a commentary on the emerging role and power of females in society. James empowered his female protagonists to depart from the norms of the Victorian era and to claim their own independence. "The Turn of the Screw" is a reflection of the changing times, as the Governess departs from a sheltered life to explore and experience life at the house of Bly, where, with very little mention of any authoritative male figures in the story, she is liberated from patriarchal society. Alice in "The Jolly Corner" helps Spencer to overcome his alter ego obsessions, feelings of fear, guilt and regret, mainly due to her wisdom, intelligence, and strong character: traits of a woman who does not fit easily into the Victorian gender stereotypes. In both novellas female protagonists occupy the positions previously available mainly to males.

The analysis of these works by Henry James, demonstrated that he paid a lot of attention to the issues of female personal freedom and self-realization resulting from society's loyalty to the institution of marriage (Boyarkina, 2008, 103). The growing tendency of alienation and misunderstanding between men and women, underlined in his short works and The Bostonians continues to be devel- 
oped in contemporary American novels and short stories about women, their families, and their destiny.

\section{REFERENCES Ames, L. T. (1886). The Bostonians. Woman's Journal, XVII, 82-83.}

Bal, M. (1997). Narratology. Toronto: University of Toronto Press.

Beard, M. (2014). The Public Voice of Women. London Review of Books. Retrieved from https://www.lrb.co.uk/the-paper/v36/n06/mary-beard/ the-public-voice-of-women.

Boyarkina, I. (2008). The Rise of Feminism in America. The Bostonians by Henry James. Byelorussian State University Journal, 2, 103-106.

Boyarkina, I. (2020). Mary Shelly's Frankenstein and Olaf Stapledon's Sirius. In: A. Gutty (Ed.), Romantic Weltleteratur of the Western World (pp. 145-159). New York: Peter Lang Publishing.

Freud, Z. (1997). Dora: An Analysis of a Case of Hysteria. NY: Touchstone.

James, H. (1984). The Bostonians. New York: Penguin Books.

James, H. (1966). The Turn of the Screw. NY: Norton.

James, H. (2001). “The Jolly Corner.” Selected Tales. London: Penguin. 550576.

Hoeveler, D. (2004). Frankenstein, Feminism, and Literary Theory. In: Ester Schor (Ed.). Cambridge Companion to Mary Shelley (pp. 45-62). Cambridge: CUP.

Kerr, H. (1972). Mediums, and Spirit-Rappers, and Roaring Radicals: Spiritualism in American Literature, 1850-1900. Urbana, III, 190-222.

Kövecses, Z. (2010). Metaphor: A Practical Introduction. Oxford: OUP.

Long, R. (1964). A Source for Dr Mary Prance. Nineteenth-Century Fiction, XIX, 87-88.

Lubbock, P. (Ed.). (1920). The Letters of Henry James, I. New York: Charles Scribner's Sons.

Matthiessen, F. \& Murdock, K. (Eds.). (1981). The Notebooks of Henry James. Chicago: University of Chicago Press.

Pavel, T. (1985). The Poetics of Plot. Minneapolis: University of Minessota Press.

Petty, L. (2005). The Political is Personal. The Feminist Lesson of Henry James's s The Bostonians. Women's studies: An Interdisciplinary Journal, 34, 377403.

Poovey, M. (1984). The Proper Lady and the Woman Writer. Chicago: University of Chicago Press.

Rimmon-Kenan, S. (2008). Narrative Fiction, London: Routledge.

Troesch, E. (2017). Before Einstein. London: Anthem Press. 
THE RISE OF FEMINISM IN THE WORKS BY HENRY JAMES...

Welter, B. (1966). The Cult of True Womanhood: 1820-1860. American Quarterly. 18 (2), 151-174.

ИРЕН БОЯРКИНА

УНИВЕРСИТЕТ "САПИЕНЦА", Г. РИМ

ФАКУЛЬТЕТ ГУМАНИТАРНЫХ НАУК И ФИЛОСОФИИ

РЕЗЮMЕ

У ИСТОКОВ ФЕМИНИЗМА В ПРОИЗВЕДЕНИЯХ ГЕНРИ ДЖЕЙМСА: НЕКОТОРЫЕ АСПЕКТЫ НАРРАТОЛОГИЧЕСКОГО АНАЛИЗА

Творчество Генри Джеймса ломает многие искусственно созданные стереотипы и зачастую затрагивают важные социальные изменения и их последствия, например, возрастающую роль и влияние женщин в обществе. Джеймс был одним из первых американских писателей, которые затрагивали в своих произведениях тему феминизма. Эта статья исследует тему феминизма в «Повороте винта», «Веселом уголке» и «Бостонцах» и подчеркивает, что в «Бостонцах» Джеймс исследует проблему возможности одновременной самореализации женщины в семье, на работе и в общественной жизни. Эта проблема по-прежнему остается одной из самых острых проблем в феминистической литературе и в наши дни; именно это делает творчество Джеймса актуальным и в 21 веке. Анализируя «Бостонцы» и новеллы Генри Джеймса, статья демонстрирует, что писатель уделяет много внимания вопросам женской личной свободы и самореализации, ограниченной преданностью институту брака. В своем творчестве Джеймс так же изображает растущую тенденцию отчуждения и непонимания между мужчинами и женщинами.

Верный принципам психологического реализма, Генри Джеймс скрупулезно изображает гендерные ограничения и стереотипы викторианского общества XIX века и помещает своих героинь в эти обстоятельства, тщательно изучая и анализируя их поведение и его мотивы. Таким образом, большинство женщин в его произведениях обладают гораздо меньшей свободой, чем мужчины. Более того, жизнь типичной женщины в тот период часто ассоциировалась с заточением, иногда напоминающим тюремное заключение. Например, безымянная гувернантка в «Повороте винта» была прикована к загородном дому в компании двух детей и экономки, миссис Гро- 
уз, безо всякого права покидать дом или даже связываться со своим работодателем. Такая изоляция очень напоминают тюремное заключение, вернее, домашний арест. Создавая своих героев и героинь в «Повороте винта», «Веселом уголке» и «Бостонцах», Джеймс в целом соблюдал основные тенденции викторианской литературы. Однако, уже в этих произведениях просматриваются признаки отхода от этих стереотипов в сторону нового представления о стремлении женщин к большей свободе и самореализации вне семейного круга.

Внимательное чтение «Бостонцев» демонстрирует как слабые, так и сильные стороны американского феминистического движения на рубеже веков: его разобщенность, неоднородность, отсутствие сильных личных убеждений в необходимости бороться за права женщин, а так же отсутствие критического понимания феминистских проблем некоторыми активистами движения. Роман может преподать активисткам-феминисткам 21-го века некоторые важные уроки: необходимость прочного единства между всеми социальными слоями, вовлеченными в борьбу, важность личного переживания гендерного неравенства и необходимость личного убеждения в борьбе за перемены, а также необходимость образования. Пример Верены учит, что невозможно вовлечь все слои населения в борьбу за права женщин, пока они четко не осознают несправедливость гендерного неравенства и необходимость борьбы с ним. Эта статья демонстрирует, что, хотя «Поворот винта» и «Веселый уголок» - это, в первую очередь, готические новеллы, в которых Джеймс в целом придерживался гендерных стереотипов викторианской эпохи, их также можно интерпретировать как комментарий к зарождающейся новой роли женщин в обществе. Джеймс позволил своим главным героиням отойти от норм викторианской эпохи и заявить о своей независимости. «Поворот винта» - это отражение времени перемен, когда гувернантка пытается уйти от привычной жизни, чтобы исследовать новые возможности в загородном поместье работодателя, где почти не упоминаются какие-либо авторитетные мужские фигуры, то есть, она (условно) не окружена патриархальным обществом. Алиса в «Веселом уголке» помогает Спенсеру преодолеть навязчивые идеи его альтер-эго, чувства страха, вины и сожаления благодаря своей мудрости, интеллекту и сильному характеру: эти женские черты отнюдь не вписываются в традиционные гендерные стереоти- 
пы викторианского общества. Примечательно, что в этих новеллах героини занимают должности, ранее доступные в основном мужчинам. Анализ этих работ Джеймса показал, что он уделял большое внимание вопросам личной свободы женщин и их самореализации, детерминированной преданностью институту брака. Растущая тенденция отчуждения и непонимания между мужчинами и женщинами, подчеркнутая в его новеллах и «Бостонцах», продолжает развиваться в современной американской литературе о женщине, ее судьбе и семье.

КлючевыЕ Генри Джеймс; феминизм; гендерные роли; гендерный анализ; словА: нарратология.

Овај чланак је објављен и дистрибуира се под лиценцом Creative Commons Ауторство-Некомерцијално Међународна 4.0 (CC BY-NC 4.0 |

https://creativecommons.org/licenses/by-nc/4.0/).

This paper is published and distributed under the terms and conditions of the Creative Commons Attribution-NonCommercial International 4.0 licence (CC BY-NC 4.0 | https://creativecommons.org/licenses/by-nc/4.0/). 